\title{
The Importance of Lizards as Frugivores and Seed Dispersers
}

\author{
A. VAlido AND J.M. Olesen
}

\section{Introduction}

Despite the accumulation of a considerable body of literature about frugivory and seed dispersal of fleshy-fruited plants by vertebrates during the last decades (e.g. reviews in Howe and Smallwood, 1982; van der Pijl, 1982; Janzen, 1983; Howe, 1986; Howe and Westley, 1988; Stiles, 1989; Jordano, 2000; Herrera, 2002), and also previous editions of the Frugivores and Seed Dispersal: International Symposium/Workshop series (namely Estrada and Fleming, 1986; Fleming and Estrada, 1993; Levey et al., 2002), the habits of reptiles as frugivorous animals and their role as seed dispersers have rarely been considered. At most, they are regarded as agents of the past (Labandeira, 2002; Tiffney, 2004).

Understandably, the literature has been dominated by studies on frugivorous birds, primates, ungulates and bats, which behave as important seed dispersers of vascular plants in many habitats. However, the pulp of fleshy fruits is also an important food resource for tortoises and turtles (MacDonald and Mushinsky, 1988; Milton, 1992; Jerozolimski, 2003) and for herbivorous and omnivorous lizards (Schoener et al., 1982; Dearing and Schall, 1992; Valido et al., 2003). Thus, one might expect that species included in both reptile groups would act as potential seed dispersers, but this has hardly ever been seriously considered. The exceptions are classic studies demonstrating the importance of herbivorous chelonians as seed dispersers (see Beccari, 1877; Borzí, 1911; Ridley, 1930; Rick and Bowman, 1961) and also some more recent publications (e.g. Racine and Downhower, 1974; Hnatiuk, 1978; Rust and Roth, 1981; Cobo and Andreu, 1988; Milton, 1992; Moll and Jansen, 1995; Varela and Bucher, 2002; Liu et al. 2004). In contrast to these animals, the reptile group upon which we focus in this chapter - the lizards (order Squamata: suborder Sauria), including around 4800 species worldwide - have received little attention as modern 
plant mutualists although there is a growing interest in their role as seed dispersers, including both the herbivorous species (e.g. Klein, 1977; Janzen, 1982; Iverson, 1985; Traveset, 1990; Hartley et al., 2000) and the omnivorous ones (e.g. Whitaker, 1987; Fialho, 1990; Valido and Nogales, 1994; Willson et al., 1996; Lord and Marshall, 2001; Olesen and Valido, 2003; Valido et al., 2003; Rodríguez-Pérez et al., 2005).

Based on a large number of observations made by naturalists, many tortoises and turtles are regarded as herbivorous (25\%; King, 1996) and most small, diurnal lizards as carnivorous. This commonly accepted wisdom is possibly related to the fact that most lizards primarily feed on small invertebrates (e.g. Greene, 1982; van Damme, 1999; Cooper and Vitt, 2002; Vitt and Pianka, 2005). However, a herbivorous diet is observed among lizards too. A strict herbivorous habit (70-100\% plant volume in the diet; see Cooper and Vitt, 2002; Espinoza et al., 2004) is generally associated with folivorous species, which are characterized by large body size, live in warm climates, and maintain high body temperatures (but see Espinoza et al., 2004, for exceptions to this rule in small, cold-climate-living lizards). For example, all Iguanidae lizards (36 species) and also the 16 Uromastyx and three Hydrosaurus species (Agamidae), and some species and populations of skinks (e.g. Corucia zebrata, Egernia spp., Tiliqua spp., Scincidae) among others, are all specialized herbivores and possess the digestive specializations necessary for efficient foliage and stem processing (e.g. Iverson, 1982; Troyer, 1984). Thus, the conclusion is that an almost pure plant diet is uncommon in this widespread and large group of vertebrates. Estimates of the proportion of true herbivorous species are in the region of 1-3\% (Iverson, 1982; Cooper and Vitt, 2002), although these values are slowly increasing as more data are becoming available on lizard diets (e.g. Espinoza et al., 2004; O'Grady et al., 2005). However, a number of small/medium-sized lizards regularly or occasionally eat some vegetable matter as well (i.e. they are omnivorous). For example, many insular species and also some mainland lizards from areas (or seasons) poor in arthropods are known to consume nectar, pollen and fruit (e.g. PérezMellado and Corti, 1993; Valido and Nogales, 1994; Traveset and Sáez, 1997; van Damme, 1999; Cooper and Vitt, 2002; Olesen and Valido, 2003, 2004; Valido et al., 2003; Espinoza et al., 2004; O'Grady et al., 2005). Fleshy fruits are, in general, low in fibre and protein, but high in soluble carbohydrates and water content (Jordano, 2000), and are thus easier to digest than foliage and stems. Therefore, these lizards can use such plant resources when other food resources, such as arthropods, are in short supply without any adaptive changes being required in the digestive tract, which is also typical of more folivorous species (Pearson, 1954; Rand, 1978; Búrquez et al., 1986; Cooper and Vitt, 2002; Olesen and Valido, 2003; Valido and Nogales, 2003; O'Grady et al., 2005).

In the rich herpetological literature, fruits are generally included within a category called 'vegetative or plant matter' and are rarely scored separately. Consequently, their importance in the diet of omnivorous lizard species has usually been underestimated. However, in the 'literature forest', the 
understorey is rich in natural history reports of lizards feeding on fruits. The first testimonies we have at hand are painted motifs on pottery from northern Peru. These ceramics date back to the Mochica culture, which lasted from 200 to $100 \mathrm{BC}$ to $\mathrm{AD} 700$ (Larco, 2001). The first written evidence appears to relate to lizards inhabiting oceanic islands: the Canary Islands (Fructuoso, 1590, reprinted in 1964; Steindacher, 1891), the Mascarene Archipelago (Leguat, 1708, reprinted in 1981; Liénard, 1842), the Galapagos Islands (Darwin, 1845) and Jamaica (Gosse, 1851, cited in Schwartz and Henderson, 1991). These early references indicate that this phenomenon was already known by some of the naturalists of this time. We also wish to draw attention to a small specific report about the importance of lizards as seed dispersers published almost 100 years ago by Antonino Borzí (Borzí, 1911). In this first true review about saurochory, ten species of lizards were included as fruit eaters and potential seed dispersers. Recently, more than 200 examples of species of lizards feeding on fleshy fruit have been cited (Olesen and Valido, 2003); thus, we conclude that they may have a wide importance as seed dispersers. Unfortunately, most of these reports do not include any data on the quantitative importance of lizards as plant mutualists, and the accounts are rarely synthesized into generalizations of broader value to ecology and evolutionary biology. Based on a search of the literature, personal communications, and our own field research, we found that lizard-plant mutualistic interactions were much more frequent than hitherto realized (A. Valido and J.M. Olesen, unpublished results). However, quantitative information about fruit removal and seeds in scats, or quality data on dispersal of seeds to safe sites and subsequent germination are extremely scarce (see Table 2 in Godínez-Alvarez, 2004). Thus, in only a few cases do we have sufficient data to make valid comparisons with the more traditional modes of seed dispersal mediated by birds or mammals (Valido, 1999; Wotton, 2002).

Our main aim in this chapter is to revisit and synthesize the available evidence for fruit-eating lizards around the world in order to call attention to the fact that lizards need to be considered as frugivores and potential seed dispersal agents, especially in certain habitats and situations. In particular in this chapter we address:

1. The geographical distribution of saurochory;

2. The morphological characteristics of fleshy fruits consumed by lizards;

3. The taxonomic affiliation of both lizard and plant species;

4. The characteristics of their role as seed dispersers.

\section{Inclusions and Exclusions from our Review}

The available data about lizards using fleshy fruits as an alimentary resource vary in quality. Most reports and personal observations are only brief, qualitative observations of lizards feeding on fleshy fruits (e.g. Uromastyx ornate; Agamidae; see Bronstein et al., Chapter 7, this volume). We have excluded all reports that did not explicitly mention fruit as a 
separate food item. It is known that many lizards readily feed on fruit in captivity (e.g. Rogner, 1997). Such observations were also excluded if the report did not include additional field observations. Thus, only data on lizards observed feeding on fruit in nature were included. In some cases, we confirmed the presence of fruit in the diet of a lizard after personal communication with authors who only reported 'plant material' in their papers. In addition, reports without clear, unambiguous statements about the direct ingestion of fruits have not been included. For example, although infrequent fruit-eating has been reported for the tuatara (Sphenodon punctatus; Sphenodontidae) from Stephens and Middle Islands, New Zealand (Walls, 1981; Southey, cited in Whitaker, 1987; Ussher, 1999), based on seeds in droppings, we did not include these observations because the fruits may have originated indirectly from the fruit-eating Hoplodactylus gecko, which is commonly consumed by tuataras (Whitaker, 1968). A summary of our data is presented in Table 6.1 (the complete list will be published elsewhere). The systematic arrangement of lizards follows the March 2005 edition of the European Molecular Biology Laboratory $E M B L$ - Reptile Database (Uetz, 2005). We also classified lizards in relation to their geographical distribution: insular, mainland and mixed species (inhabiting islands and mainland) according to the EMBL database. Near-

Table 6.1. Taxonomic and geographical distribution of fruit-eating lizards.

\begin{tabular}{|c|c|c|c|c|c|c|c|}
\hline Fruit-eating lizards & $\begin{array}{c}\text { Number of } \\
\text { species }\end{array}$ & $\begin{array}{l}\text { Fruit-eating } \\
\text { lizards }\end{array}$ & Islands & Mixed & Mainland & $\mathrm{P}$ & $\%$ \\
\hline Scincidae & 1306 & 63 & 36 & 3 & 24 & $* * *$ & 4.8 \\
\hline Gekkonidae & 1081 & 20 & 18 & 0 & 2 & $* * *$ & 1.9 \\
\hline Polychrotidae & 393 & 45 & 41 & 0 & 4 & $\star * *$ & 11.5 \\
\hline Agamidae & 379 & 11 & 5 & 0 & 6 & * & 2.9 \\
\hline Tropiduridae & 309 & 38 & 17 & 0 & 21 & 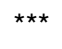 & 12.3 \\
\hline Lacertidae & 280 & 27 & 17 & 2 & 8 & $\star \star \star *$ & 9.6 \\
\hline Phrynosomatidae & 125 & 7 & 1 & 0 & 6 & ns & 5.6 \\
\hline Teiidae & 122 & 24 & 9 & 3 & 12 & $* * *$ & 19.7 \\
\hline Anguidae & 112 & 1 & 1 & 0 & 0 & ns & 0.9 \\
\hline Varanidae & 59 & 2 & 2 & 0 & 0 & * & 3.4 \\
\hline Cordylidae & 54 & 2 & 0 & 0 & 2 & ns & 3.7 \\
\hline Iguanidae & 36 & 20 & 15 & 3 & 2 & * & 55.6 \\
\hline Gerrhosauridae & 33 & 6 & 4 & 0 & 2 & ns & 18.2 \\
\hline Xantusiidae & 24 & 3 & 2 & 0 & 1 & $\star \star *$ & 12.5 \\
\hline Dibamidae & 20 & 5 & 5 & 0 & 0 & ** & 25.0 \\
\hline Crotaphytidae & 10 & 2 & 0 & 1 & 1 & ns & 20.0 \\
\hline Corytophanidae & 9 & 3 & 0 & 0 & 3 & ns & 33.3 \\
\hline Opluridae & 7 & 1 & 1 & 0 & 0 & ns & 14.3 \\
\hline Total & 4359 & 280 & 174 & 12 & 94 & $* * *$ & 6.4 \\
\hline As percentage & & & 62 & 4 & 34 & & \\
\hline
\end{tabular}

$\mathrm{P}$, the probability that the sample of lizards differs from random (see Results). The last column is the percentage of the total of fruit-eating lizards. 
shore islets were regarded as part of the adjacent mainland. For plant genera we followed Mabberley (1997). In the analysis we used MATLAB (Matworks, Natrick, Massachusetts, USA).

\section{Synthesis of Data}

\section{Frugivorous lizards}

From all the reports and observations included in our review, we found a total of 280 species of lizards from 85 genera and 18 families that consume fleshy fruits at least occasionally (Table 6.1). These observations originate from 45 islands/archipelagos and 30 mainland countries (e.g. Spain, Iran, Argentina). Fruit consumption is more often reported from islands (62\%) than from mainland populations (34\%). Species observed to eat fruit on both mainland and island regions only constituted 4\% (see Fig. 6.1). Overall, there were many more frugivorous species on islands than would be expected by chance (Table 6.1; see below). Island species were significantly over-represented as fruit consumers in 11 out of the 18 lizard families, especially in Polychrotidae $(91.1 \%$ of the registered cases), Gekkonidae $(90.5 \%)$, Lacertidae $(63 \%)$ and Scincidae $(56.9 \%)$.

To test the null hypothesis stating that the observed distribution of frugivorous lizards is equivalent to the distribution of species between islands, islands + mainland, and mainland, we used a one-tailed Fisher's exact test for $\mathrm{N} \times \mathrm{M}$ contingency tables (Wells and King, 1980). Here we use as our database only the 18 lizard families (including a total of 4359

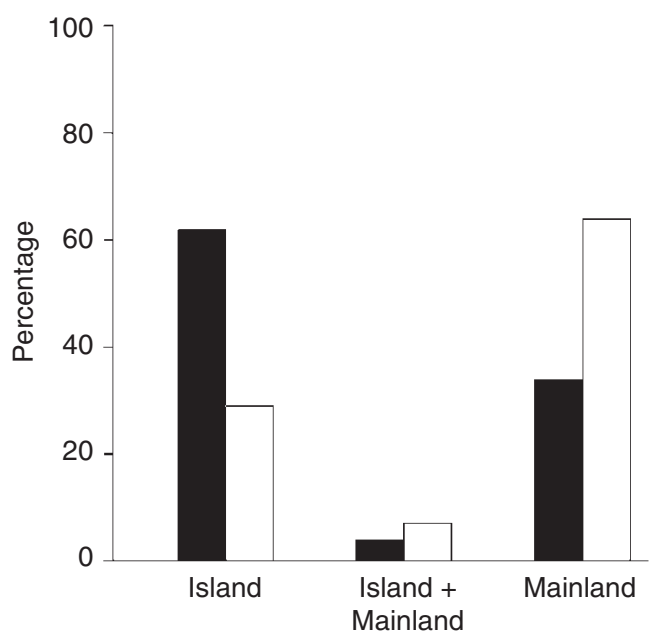

Fig. 6.1. The proportion of fruit-eating lizards (solid bars) compared with all other species (open bars) of lizard (Scincomorpha: Iguania, Gekkota, Scincomorpha) inhabiting islands, mainland or mixed. Data on geographical distributions of lizards from Uetz (2005). 
species) in which frugivory is known. According to the EMBL Reptile Database, $30 \%, 7 \%$ and $63 \%$ of all species in these families are from islands (I), islands + mainland (IM) and mainland (M), respectively (Uetz, 2005). If we then draw a species randomly from the total pool of 4359 species, the probability of drawing an I-species must be $p_{\mathrm{I}}=0.30$, an IM-species is $p_{\text {IM }}=0.07$, and an M-species is $p_{\mathrm{M}}=0.63$. The probability $P$ of drawing two island species in a draw of two species is $P=p_{\mathrm{I}}{ }^{2}=0.30^{2}$. The probability $P$ of drawing, for example, one I-species, two IM-species and two M-species from a trinomial random draw of five species is:

$$
P=\left(\begin{array}{c}
5 ! \\
1 ! 2 ! 2 !
\end{array}\right) p_{\mathrm{I}}^{1} p_{\mathrm{IM}}^{2} p_{\mathrm{M}}^{2}=0.017
$$

The general likelihood is

$$
P=\left(\begin{array}{c}
n ! \\
r_{\mathrm{I}} ! r_{\mathrm{IM}} ! r_{\mathrm{M}} !
\end{array}\right) p_{\mathrm{I}}^{r_{\mathrm{I}}} p_{\mathrm{IM}}^{r_{\mathrm{IM}}} p_{\mathrm{M}}^{r_{\mathrm{M}}}
$$

where $n$ is sample size, $r_{\mathrm{I}}$ is number of I-species, $r_{\mathrm{IM}}$ is the number of IMspecies and $r_{\mathrm{M}}$ is the number of M-species.

We have compiled a list of 280 species of lizards consuming fleshy fruits. Our review documented that 174 were island species, 12 occurred both on islands and mainland, and 94 were from mainland locations only (Table 6.1). We now want to know whether this is a random draw from the total species pool. To find out the exact probability, we computed the sum of $P$ values by generating all tables that are more extreme than the table given, i.e. more island species. Exact $p$-values tend to be more conservative, since we are including all cell frequencies with the same fixed marginal totals as the observed one. The probability of getting our sample or one that is even more island-skewed was $P=1.55 \times 10^{-29}$. Thus, many more frugivorous species occur on islands than would be expected by chance.

This pattern also holds true at the family level. We repeated the same calculations as above for each family (Table 6.1). Island species consuming fruit are highly over-represented in 11 of the 18 families. Exceptions are: Anguidae, Crotaphytidae, Cordylidae, Phrynosomatidae, Corytophamidae, Opluridae and Gerrhosauridae. However, in these families, the number of fruit-eating lizards was very small.

\section{Lizard plants}

Worldwide, a total of 414 species, 206 genera and 101 families of plants with fleshy fruits have been reported in the diet of these 280 species of lizards. This figure is clearly an underestimate, since many reports lack data about the identity of the species whose fruits are consumed (e.g. Auffenberg and Auffenberg, 1988; Belver and Avila, 2002). In spite of this shortcoming, these results reveal some interesting patterns that need to be considered in future studies. For example: 
1. Lizards consume fruits that are very diverse in type, size and colouration. 2. Fruit consumption occurs on island and mainland areas from a wide latitudinal range.

3. Fruit consumption by lizards is recorded from all continents and many oceanic islands.

In short it is a very widespread phenomenon affecting plants with a wide range of fruit structures.

From this lizard-fruit database, five families: Moraceae (with 30 species), Palmae (27), Rubiaceae (25), Solanaceae (25) and Cactaceae (24) account for $34 \%$ of all species of plants that lizards feed on. Most species are scattered widely in the phylogenies of the angiosperms and gymnosperms. The fruit types consumed are highly diverse: including syconium (e.g. Ficus spp.; Moraceae); arcestid (e.g. Juniperus phoeniceae; Cupressaceae); berry (e.g. Hippomane mancinella; Euphorbiaceae); drupe (e.g. Corynocarpus laevigatus; Corynocarpaceae); polydrupe (e.g. Rubus inermis; Rosaceae); and arillate seed (Annona araracuara; Anonnaceae).

This diversity in fruit types is also seen in their coloration. We looked for associations between fruit colour and consumption by lizards by comparing the colours of species consumed by lizards to the colour spectrum of the fleshy fruits available. We used data from three distant archipelagos, the Canary Islands (Fig. 6.2), the Balearic Archipelago (Fig. 6.3) and New Zealand

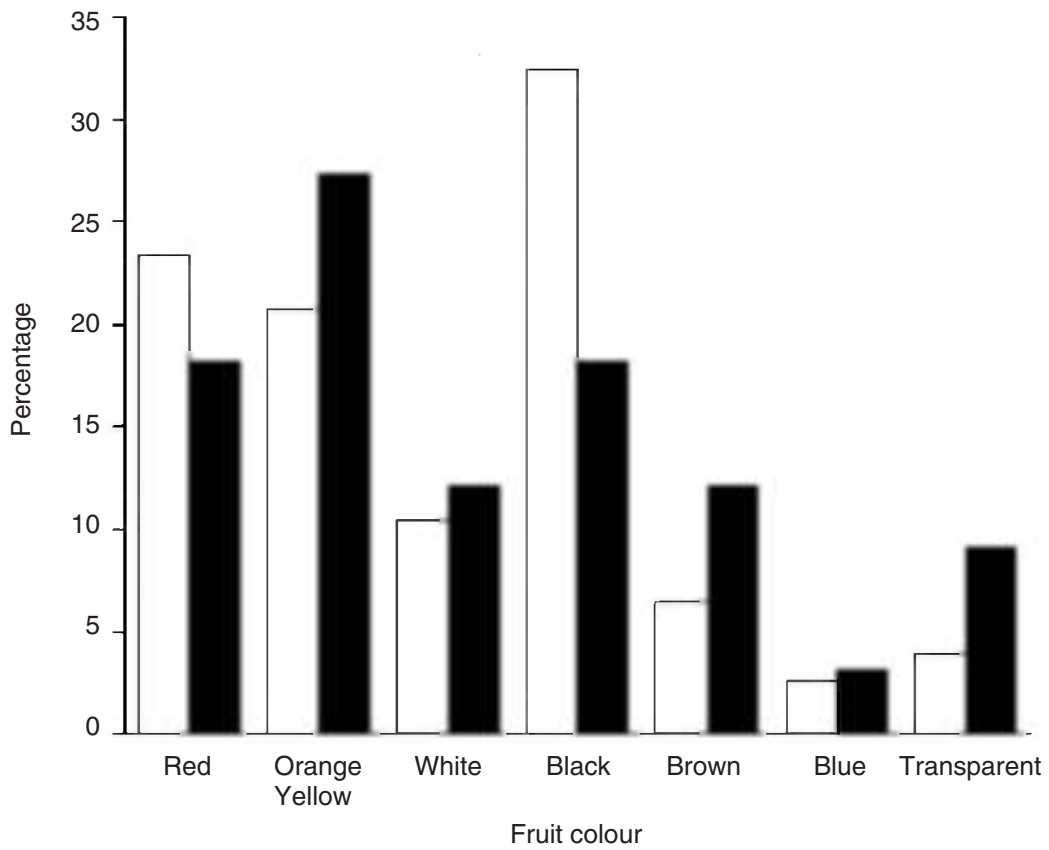

Fig. 6.2. A comparison of the proportion of colours of fleshy-fruited native plants from the Canary Islands (open bars) and those reported in the diet of the endemic lacertid species (Gallotia spp.) inhabiting these islands (solid bars). Data from Valido (1999). 


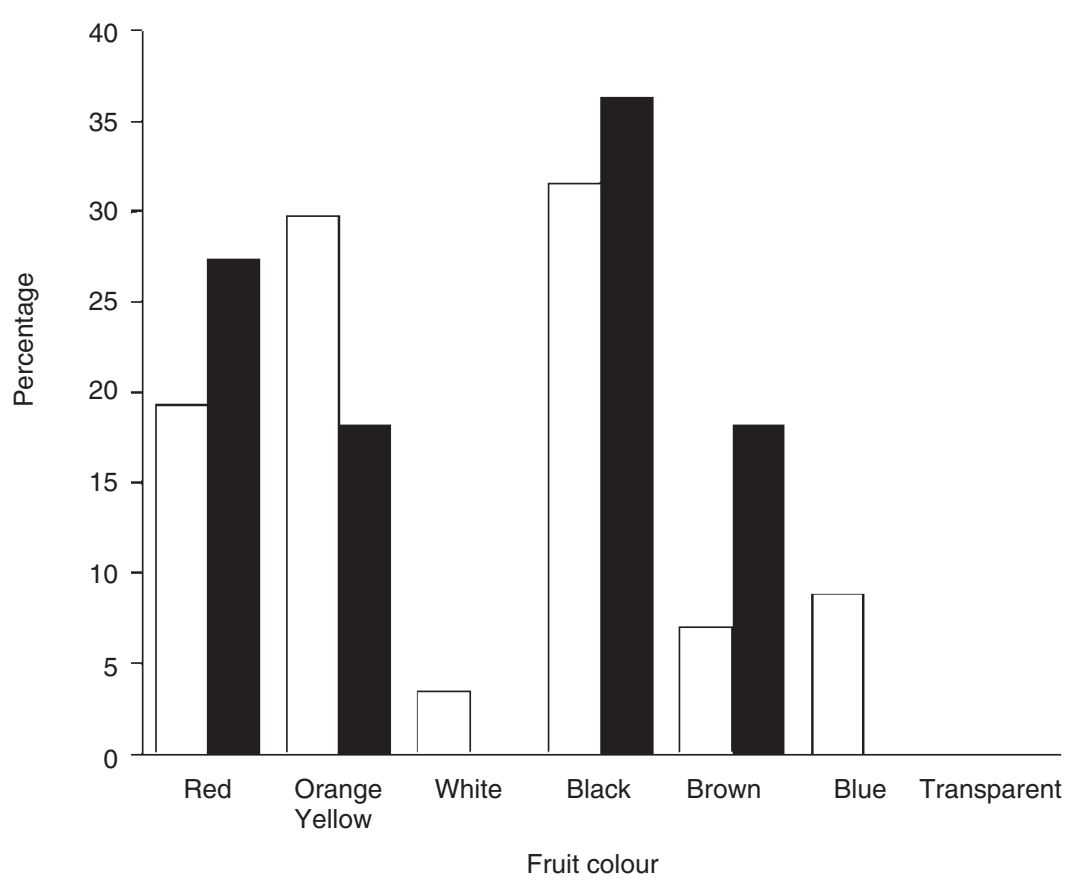

Fig. 6.3. A comparison of the proportion of colours of fleshy-fruited native plants from the Balearic Archipelago (open bars) and those reported in the diet of the lacertid Podarcis lilfordi (solid bars). Data from Pérez-Mellado and Traveset (1999) and the Balearic Virtual Herbarium (http:// herbarivirtual.uib.es).

(Fig. 6.4), which are all well represented in our lizard-fruit data set. We looked for any association between colour of fruit consumed by lizards and colour spectrum of fleshy fruits on these three archipelagos. Lord and Marshall (2001) and Lord et al. (2002) presented frequency distributions of colours of fleshy fruit for a large sample of New Zealand species. In our analysis, we used their data but lumped several of their colour categories (pink into red, yellow and orange; and purple into black). In addition, we introduced a 'transparent' fruit colour category, and placed the New Zealand Muehlenbeckia and the Canarian Rubia fruticosa, Plocama pendula (Rubiaceae) and Jasminum odoratissimum (Oleaceae) into this category. Canarian and Balearic data came from our own database and the Balearic 'virtual herbarium' (http://herbarivirtual.uib.es/), respectively. The numbers of species producing fleshy fruit were 77, 57 and 216, from the Canary Islands, the Balearic Archipelago and New Zealand, respectively. The numbers of fleshy-fruited species consumed by lizards in these three archipelagos were 41,11 and 14 , respectively.

The distributions of fruit colours in the flora from these distant areas were similar. As in most floras, colours such as red, yellow-orange and black constitute a majority of species (> 75\%). Less well represented (12-16\%) are white, blue and transparent colours. However, in spite of very similar fruit 


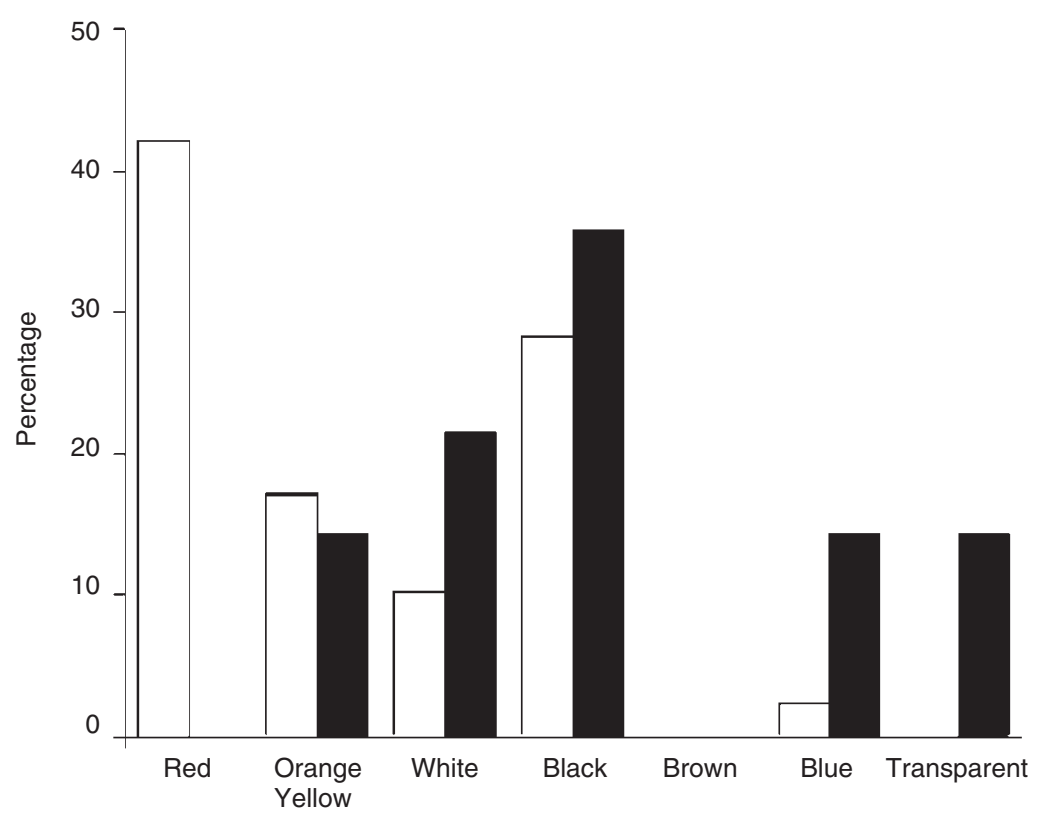

Fruit colour

Fig. 6.4. A comparison of the proportion of colours of fleshy-fruited native plants from New Zealand (open bars) and those reported in the diet of lizard species (solid bars). Data from Whitaker (1987), Lord and Marshall (2001) and Lord et al. (2002).

colour spectra from the three archipelagos, lizard preferences varied. For example, in contrast with data obtained from the New Zealand flora, there were no fruit colours particularly associated with saurochory in either the Canarian flora (Fig. 6.2) or the Balearic ones (Fig. 6.3). For example, unlike the New Zealand frugivorous lizards (see Lord and Marshall, 2001; Lord et al., 2002), red (Tamus edulis; Dioscoreaceae), black (Rhamnus crenulata; Rhamnaceae), white (Bencomia caudata; Rosaceae), orange (Canarina canariensis; Campanulaceae) and translucent (Plocama pendula; Rubiaceae) fruits, which can be up to $27 \mathrm{~mm}$ in diameter (Canarina canariensis) with seeds up to $9 \mathrm{~mm}$ in diameter and the number of seeds per fruit up to 1395 (in Canarina canariensis) are heavily consumed in different habitats and islands by the Canarian lizards (Gallotia spp.; Lacertidae).

\section{Lizards as Frugivorous Vertebrates}

Our review and analysis reveal that fleshy fruits may be a more important food resource to some species of lizards than hitherto recognized in the specific literature about frugivores and seed dispersal. A remarkable result of our compilation of 280 fruit-eating species is that it is not only classical herbivorous lizards, such as the Iguanidae, that eat fruits. The omnivorous 
and, surprisingly, many other species commonly considered to be truly insectivorous and/or carnivorous consume fruits as well. For example, within the Varanidae, which is usually considered a strictly carnivorous family, some species from Malaysia and the Philippines have been reported as feeding extensively (Varanus olivaceus - Auffenberg, 1988; Bennett, 2005), mostly (Varanus mabitang - Struck et al., 2002) or sporadically on fleshy fruits (Varanus spp. - Yasuda et al., 2005).

All major lineages of vertebrates use fruit as an alimentary resource, but birds and mammals are generally considered to be the only significant dispersers of seeds for vertebrate-dispersed plants. Fleming (1991) reported that $35.5 \%$ of bird and $19.6 \%$ of terrestrial mammal families contain species that, in some instance, use fruits as a food resource. However, among birds these values are lower (15.5\%) if we only consider strictly frugivorous species with a nearly total fruit diet (Jordano, 2000). For lizards, we found that species from $69 \%$ of the 26 lizard families (at least $6 \%$ of all species) consume fleshy fruit in some quantity. However, since more attention is now being paid to this type of plant-animal mutualism, more cases are likely to be added in the near future. For example, there are records of lizards consuming flowers (e.g. Sceloporus jarrovi - Ballinguer and Ballinguer, 1979; Liolaemus donosoi - Ortiz, 1975), seeds (e.g. Agama yemenensis - Al-Johany, 1995), nectar (e.g. Anolis conspersus - Echternacht et al., 2000; Rhacodactylus auriculatus - Bauer and Sadlier, 2000), sap (e.g. Gehyra australis - Greer, 2005; Phelsuma spp. from Madagascar - Fölling et al., 2001), pollen (e.g. Phelsuma sundbergi - Murphy and Myers, 1996; Liolaemus platei - Weiser et al., 1975) and foliage (e.g. Acanthodactylus erythrurus - Busack and Jasick, 1982; Podarcis milensis Adamopoulou and Legakis, 2002). At least some of these omnivorous species may be found to eat fleshy fruits as well. However, in order to make a more precise comparison of the relative importance of birds, mammals, reptiles and fish as frugivores, we need to know both the total number of frugivorous species in each group and also the quantitative importance of fruit in their diet. Unfortunately these data are not available for all groups.

Seed dispersal by reptiles was probably the most primitive condition (Tiffney, 2004). As birds and mammals evolved, they became the main dispersal agents in many habitats. However, the herbivory (or in some cases, frugivory) condition was retained in some chelonians and also in the most primitive extant lizard family, the Iguanidae (Estes, 1983). These two reptile groups are the two most commonly used examples of seed dispersers in the frugivory literature when reptiles are cited. However, some modern species of lizards, traditionally considered primarily carnivorous or insectivorous, 'regain' this relict function when other food resources (i.e. arthropods) are no longer available (see below).

Another interesting conclusion to be drawn is that frugivorous lizards are geographically widespread but occur disproportionately on islands. For example, although insular species constitute less than one-third of all recognized species worldwide (Fig. 6.1; Uetz, 2005), they are significantly over-represented in our lizard-frugivory database. 


\section{Why Islands?}

Island food-webs are relatively more simple than those from the mainland areas. The difference arises because of a lower species diversity (Carlquist, 1974), taxonomic disharmony (some groups are absent or poorly represented; Baur, 1891), and high densities of certain taxa (i.e. density compensation: an increase in abundance in the absence of interspecific competitors; MacArthur et al., 1972) on islands. In this respect, species-poor islands are generally characterized by the presence of an extremely high density of lizards (see Table 2 in Rodda and Dean-Bradley, 2002). For example, the terrestrial vertebrate with the highest recorded density is Sphaerodactylus macrolepis (Gekkonidae) from Guana Island (67,600 individuals $\mathrm{ha}^{-1}$; Rodda et al., 2001). Only limited data are available on arthropods. It is known that island areas are likely to have relatively fewer species of insects than nearby mainland areas (Janzen, 1973; Ebenman and Nilsson, 1982). This pattern is evident in flower visitors; a lower number of pollinators have been detected visiting island plants compared with conspecific mainland populations (Barrett, 1998; Olesen and Jordano, 2002; J.M. Olesen and A. Valido, unpublished results). Thus, high densities in island lizards, together with arthropod scarcity and a reduced exposure to predation, may force predominantly arthropod-eating lizards to expand their trophic niche by exploiting other available resources: fruits being an important one (Olesen and Valido, 2003). Pulp from fleshy fruit is less energy-rich than other animal food items (i.e. insects), providing fewer calories and less protein per gram than animals do (see Table 6.3 in Jordano, 2000), but it is a food resource present in most island habitats.

In several families of lizards, frugivory (or omnivory) and insularity are significantly correlated (van Damme, 1999; Cooper and Vitt, 2002; see also Table 6.1). This pattern is also evident when comparing island-mainland populations within species. For example, in 1960 the large (>500 mm snout-vent length) Tupinambis merianae (Teiidae) was introduced from the South American mainland to Fernando de Noronha Archipelago $345 \mathrm{~km}$ off the north-eastern Brazilian coastline (Péres, 2003). On the Archipelago it includes a higher proportion of plant material, especially fruits of both native and introduced species, into its diet than in its original mainland habitat (Mercolly and Yanosky, 1994; Kiefer and Sazima, 2002). Other known examples from omnivorous species are populations of Podarcis hispanica (Lacertidae) from the Iberian Peninsula (Mellado et al., 1975) compared with populations from Columbretes Islands (Castilla and Bawens, 1991), and Cnemidophorus lemniscatus and Ameiva ameiva (Teiidae) from Providence Island (Janzen, 1973) which are more omnivorous than populations in several localities on the mainland (e.g. Vega et al., 1988; Magnusson and da Silva, 1993; Vitt and Carvalho, 1995; Colli et al., 1997). Although clearly more data are necessary, these intraspecific comparisons suggest that the increase in the use of fleshy fruits by island lizards is in part due to some common ecological factors occurring in these insular habitats. The use of phylogenetic contrast analysis or independent pair-wise comparisons (in the absence of a fully 
resolved phylogeny) and controlling for lizard size variation would be the next step in testing this ecological pattern.

The arthropod-scarcity hypothesis can also be extended to other habitats characterized by a constant or seasonal scarcity of animal prey. For example, high mountains, arid regions and caves are lacking in arthropods compared with most other habitats (Mautz and Lopez-Forment, 1978; Pietruszka et al., 1986). Several skinks (Scincidae) from arid regions consume plant material during dry periods when arthropods are scarce (Kuchling, 1970; Symon, 1979; Schleich et al., 1996). In general, insects are scarcer in dry seasons than in the wet seasons (Churchill, 1994; Griffiths and Christian, 1996; Christian et al., 2003), and such a seasonal scarcity of arthropod food may select for omnivory in lizards.

\section{Lizards as Seed Dispersers?}

In 1985, the herpetologist John B. Iverson used this query to title a short note calling attention to the role of herbivorous lizards as seed dispersers. In the note, he analysed the percentage of germination for seeds removed from the droppings of the iguanas Cyclura rileyi and C. carinata from the Bahamas and the Turks and Caicos Islands. An increase (although not statistically significant) in seed germination in Coccoloba uvifera (Polygonaceae) seeds passing through the digestive tract (43.8\%), compared with control seeds $(27.5 \%)$, was observed. Although without control seeds for comparison, high levels of germination (85\%) were obtained for Casasia clusiaefolia (Rubiaceae) seeds collected from Cyclura faecal pellets. In this pioneer contribution, the author pointed out that lizards can be considered as legitimate seed dispersers, since seeds were not damaged and germination was enhanced in some cases, even though the average passage time through a lizard gut is around 4 days (Iverson, 1985). As far as we know, this is the first published experimental evidence showing that lizards are legitimate seed dispersers. However, more examples are necessary in order to generalize Iverson's (1985) results and to compare them with results obtained from other frugivore groups (birds and mammals).

Fortunately, in recent decades there have been some studies undertaken, and about 25 papers dealing with the effects of seed passage through lizard guts have been published (reviewed in Traveset, 1998; Traveset and Verdú, 2002; A. Valido, unpublished results). They cover 40 plant species belonging to 17 families, and 17 lizards belonging to seven families. Although the number of experiments with lizards were much fewer than similar bird (153) and mammal (119) experiments, seeds consumed by lizards germinated just as well as seeds consumed by birds and mammals. The proportion of examples where germination of the seeds passing through the digestive tract of lizards was enhanced (25\%), unaffected $(57 \%)$ or inhibited (18\%) was similar $\left(\chi^{2}\right.$ test; $\left.P=0.28\right)$ to those observed when birds $(36 \%, 48 \%, 16 \%$, respectively), non-flying mammals $(39 \%, 42 \%, 19 \%)$ and bats $(25 \%, 67 \%, 8 \%)$ were the frugivorous species (Traveset, 1998). 
A more interesting comparison would be to know the outcome of passage through a lizard digestive tract relative to other sympatric native frugivores (birds and mammals) for the seeds of a given species of plant. Greeff and Whiting (1999) observed no significant differences in germination success of Ficus cordata (Moraceae) seeds collected from lizard (48\%; Platysaurus broadleyi; Cordylidae), bird (34\%; mostly Onychognathus nabouroup and Pycnonotus nigricans) and rock hyrax (29\%; Procavia capensis) droppings and controls (48\%). In other tri-species comparisons, MoralesMávil et al. (2005) showed that seeds being dispersed by Iguana iguana had a higher percentage of germination (86.7\%) than those from spider monkey, Ateles geoffroyii (45\%), toucan, Ramphastos sulfutarus (33.3\%) or controls (20\%). In contrast, Mandujano et al. (1994) showed that endocarps consumed by Ctenosaura pectinata (Iguanidae) germinated less successfully $(35 \%)$ than those consumed by white-tailed deer (Odocoileus virginianus; $72 \%)$ or controls $(63 \%)$.

In studies comparing the germination of seeds passed through lizards and birds, similar results were obtained. For example, seeds from Plocama pendula and Rubia fruticosa (Rubiaceae) dispersed by sylviid warblers (Sylvia spp.), lacertid lizards (Gallotia spp.) and control (Valido, 1999; Nogales et al., 2005) all showed a similar percentage germination. An analogous result was also found by Rodríguez-Pérez et al. (2005) for several Mediterranean plant species being dispersed by lizards and birds. Reanalysing their data, we found that seeds obtained from blackbird (Turdus merula) and Podarcis pityusensis (Lacertidae) droppings and controls resulted in a similar germination success for Rhamnus alaternus (Rhamnaceae), Rubia peregrina (Rubiaceae), Rubus ulmifolius (Rosaceae), Solanum luteum and Solanum nigrum (Solanaceae). In addition, an increase in the germination success of seeds passed through lizards was obtained for Rhamnus ludovici-salvatoris (Rhamnaceae) compared with seeds that had passed through birds.

Thus, according to these comparisons, a cautious preliminary answer to Iverson's question would be 'yes': lizards can be regarded legitimate seed dispersers in the same way as frugivorous birds and mammals with regard to the effects on germination of the passage of seeds through the digestive tract.

Whether an animal is a legitimate disperser is just one of the aspects to take into account when we want to know the contribution of seed dispersers to plant fitness (seed dispersal effectiveness; sensu Schupp, 1993). To be effective as a seed disperser, lizards must transport viable seeds beyond the parent plant, and deposit them in a site where their chances of survival to adult plants are good. Accordingly, effectiveness can be analysed quantitatively (related to number of seeds being dispersed) and qualitatively (related to the probability that a seed will recruit a new adult individual) (Schupp, 1993; Jordano and Schupp, 2000; Schupp, Chapter 20, this volume). Only two studies (both from islands: Valido, 1999; Wotton, 2002) simultaneously included several aspects of the qualitative and quantitative components of lizard disperser effectiveness. The species studied were Gallotia galloti (Lacertidae) and Plocama pendula 
(Rubiaceae) from the Canary Islands (Valido, 1999), and Hoplodactylus maculatus (Gekkonidae) and Croprosma propinqua (Rubiaceae) from New Zealand (Wotton, 2002). The studies showed that these omnivorous lizards appeared to be effective seed dispersal agents because: (i) the lizards removed a considerable proportion of fruits from plants; (ii) the ingestion of seeds had no detrimental effect on germination success; and (iii) the lizards tended to deposit seeds in microhabitats where the probability of germination and seedling establishment was improved more frequently than in hostile microhabitats. These results, although only based on two examples, demonstrate that lizards may be considered to be effective seed dispersers.

Although more the study of cases is necessary before we can conclude that lizards are generally effective dispersers, additional evidence, including some of the aspects of the quantitative component of effectiveness, have been found with different species of lizards which may support this conclusion. Extensive use of fleshy fruits (high frequency of occurrence or volume; $>40 \%$ ) in the diet has been found in: Ameiva exsul (Patterson, 1928), Ameiva ameiva and Cnemidophorus lemniscatus (Janzen, 1973), Anolis equestris (Brach, 1976), Liolaemus nigromaculatus (Ortiz and Riveros, 1976), Podarcis spp. (Salvador, 1986; Pérez-Mellado et al., 2005), Leciocephalus carinatus (de Armas, 1987), Darevskia rudis (Franzen, 1991), Klentropyx striatus (Magnusson and da Silva, 1993), Tropidurus torquatus (Côrtes-Figueira et al., 1994), Lacerta lepida (Hódar et al., 1996), Cnemidophorus lemniscatus (Vitt et al., 1997), Gallotia spp. (Valido et al., 2003; Valido and Nogales, 2003), Anolis garmani (Herrel et al., 2004) and Psammodromus algirus (Calviño-Cancela, 2005), among others.

Although most lizards are not as mobile as many birds and mammals, and long-distance seed dispersal is uncommon, lizards can be effective in transporting seeds sufficiently far away to avoid density-dependent mortality, which may occur below the parent plants. For example, Greeff and Whiting (1999) observed dispersal distances up $187 \mathrm{~m}$ in the case of seeds of Ficus cordata (Moraceae) being dispersed by Platysaurus broadleyi (Cordylidae) from South Africa. Whitaker (1968) recorded $73 \mathrm{~m}$ as the maximum distance movement by Hoplodactylus duvaucelli (Gekkonidae) in New Zealand. This author also found dispersed seeds $12 \mathrm{~m}$ away from the nearest fruiting plants (Whitaker, 1987). Barquín and Wildpret (1975) cited up to $50 \mathrm{~m}$ for seeds of Plocama pendula (Rubiaceae) being dispersed by Gallotia galloti from the nearest potential parent plant. Côrtes-Figueira et al. (1994) reported $6.9 \mathrm{~m}$ as maximum dispersal distance of Melocactus violaceus (Cactaceae) seeds by Tropidurus torquatus (Tropiduridae). Using spatial distribution of seedlings of Daphne rodriguezii (Thymelaeaceae) from a population where seeds of this species are only being dispersed by lizards (Podarcis lilfordi), Traveset and Riera (2005) estimated dispersal distances up to $4 \mathrm{~m}$ away from any reproductive adult. However, longer seed dispersal distances would be possible because a gut passage time of 4 days has been reported for this species (Traveset and Riera, 2005). These different seed dispersal distances may be due to differences in lizard body size, gut passage time, alternative 
food sources, environmental temperature, foraging patterns and social behaviour, among others.

Another important aspect to consider in relation to quality of seed dispersal is that lizards may also deposit considerable quantities of seeds in places suitable for germination and subsequent plant recruitment for the plants they are dispersing, including cracks and crevices in rocks, or sheltered places adjacent to stones (e.g. Whitaker, 1987; Valido and Nogales, 1994; Valido, 1999; Wotton, 2002; Benítez-Malvido et al. 2003; but also see Fialho, 1990). Generally, these areas show some common characteristics, for example they have relatively high humidity, low aridity and low predation rates. Lizards may potentially also be responsible for vegetation composition and distribution in such habitats (Valido and Nogales, 1994).

\section{A Lizard Fruit Syndrome?}

Fruit syndromes (correlated fruit traits associated with some particular group of frugivores) have been a classical topic in the frugivory literature. For example, small brightly coloured fruits persisting on plants after ripening have generally been associated with birds, while large green/brown-coloured fruits that fall to the ground after ripening are associated with mammals (e.g. Herrera, 2002). A fruit syndrome for reptiles was first proposed by Borzí (1911), possibly based on earlier observations by Beccari (1877). He proposed three tentative types of saurochorous fruits based on what was known at that time: (i) the Scioide (which included Ficus, Capparis and Opuntia fruits); (ii) the Arum; and (iii) the Viola types. In addition, Borzí formulated the idea that the presence of fruits on the trunk near the ground (caulicarpy) could be an adaptation to seed dispersal by reptiles. Later, van der Pijl (1969, re-edited in 1982) proposed that reptile-fruits are aromatic, coloured, and may be borne near the ground on a trunk or dropped to the ground when ripe. This description is probably based on the fact that the classical reptile-fruit known in van der Pijl's time, Gingko biloba (Ginkgoaceae), clearly fits this description: 'greenish drupe-like ovule-seeds with a faint smell which fall to the ground' (p. 131; van der Pijl, 1982). Nowadays, many examples are known that do not fit this syndrome; many lack odour and colours vary widely. For example, Varela and Bucher (2002) found that the odourless fruit of Celtis pallida (Ulmaceae) and Capparis atamisquea (Capparaceae) had a high frequency of occurrence (59\%) in Teious teyou (Teiidae) droppings. Several odourless lizard-fruits are known from the Balearic Archipelago (Pérez-Mellado and Traveset, 1999) and the Canary Islands (Valido et al., 2003) as well.

Recently, and using a comprehensive database of fruit characters from the New Zealand flora ( $n=246$ plant species), Lord and Marshall (2001) and Lord et al. (2002) found some support for a lizard-fruit syndrome. They suggest that lizards may be of importance in the evolution of fruit 
from shrub species with divaricated branches, growing in open, dry habitats. They also proposed that fruit-eating lizards favour small, elliptically shaped, white or pale-blue to sky-blue fruits. Captive Oligosoma lizards prefer blue and white Coprosma fruit to white and red ones. However, as Lord et al. (2002) also point out, this lizard dispersal syndrome cannot be applied to other floras, and differences can be related to the taxonomic composition of the lizard fauna. The guild of frugivorous lizards from New Zealand consists of six species of Gekkonidae and 13 species of Scincidae (Whitaker, 1987, and references therein; Patterson, 1992; Cogger et al., 1993; Spencer et al., 1998). Many of these lizards (e.g. the geckos Hoplodactylus spp.) are nocturnal, whereas practically all the Oligosoma skinks are diurnal. It is likely that this lizard-fruit syndrome described for New Zealand is location-specific and cannot be applied to other areas. For example, a comparison of the frequency of fruit colours in lizard diets from the Canary Islands (Fig. 6.2) and the Balearic Archipelago (Fig. 6.3) floras with the New Zealand flora (Fig. 6.4) show distinct differences. This is likely to be caused (in part) by practically all the frugivorous lizards from the Canaries and the Balearic Archipelago being diurnal lacertids.

In addition, we need to incorporate information about the evolution of Squamata feeding strategies (Vitt, 2004) and plant phylogeny (Jordano, 1995), in order to test for any association of fruit traits with frugivory in lizards. For example, the Iguania lizards use visual signals to detect prey and their tongue to capture it. Gekkota species, on the other hand, use visual and olfactory prey discrimination, and use their mouth for capture and tongue for cleaning face and eyes. Scincomorpha use visual cues and their vomeronasal organs in chemical discrimination. Visual prey detection may be the primitive state (see Fig. 1 in Vitt, 2004). This means that plants whose fruits are consumed and seeds dispersed by different lizard clades are under very different selection pressures according to the predominant cues used by different lizard taxonomic groups for food selection. With respect to plants, Jordano (1995) found that the evolutionary history of lineages accounts for a great proportion of the variation in fruit traits, and only fruit size (diameter) showed an important interspecific variability independent of phylogeny. Thus, if lizards are important selective agents on fruit traits, we may one day discuss a gecko fruit syndrome and an iguanid fruit syndrome, among others, similar to the distinction between different mammal groups, such as bat-fruit and primate-fruit syndromes.

\section{Avenues for Future Research}

Although lizard frugivory and seed dispersal are of particular relevance in some specific geographical situations (principally islands, but also xeric habitats), this topic is a slowly emerging research focus within mutualism studies in general, and seed dispersal research in particular. However, since little has been published on the topic of seed dispersal by lizards, any current 
interest on ecological and evolutionary plant-frugivore interactions (e.g. Herrera, 2002), including some aspects already published in this volume (e.g. digestive treatment (Traveset et al., Chapter 4), spatial patterns of seed shadows (Dennis and Westcott, Chapter 9), demographic consequences (Godínez-Alvarez and Jordano, Chapter 17) and consequences of frugivore extinction (Silva et al., Chapter 26)) are also relevant for studies focusing on lizards. We have shown that a frugivorous diet is more common in lizards than previously appreciated, but at the same time, many information gaps (e.g. lizard diet) have hampered our efforts to make solid generalizations, especially in relation to island species (see a compilation of the herpetological literature at http://www.herplit.com/).

Apart from this necessary basic natural history information, the next step is to compare patterns of frugivory and the process of seed dispersal by lizards to that by birds and mammals in an attempt to establish the importance of lizards for plant regeneration. Earlier we highlighted several future research directions and several key questions that have emerged from our analyses, which focus on the interactions between frugivorous lizards and plants. When more data become available from more sites, a clearer understanding of the importance of lizards as seed dispersers will emerge. Particularly important is their relevance to conservation, since lizards may be the only seed dispersers of some species of plants, for example Withania aristata (Solanaceae), Neochamaelea pulverulenta (Cneoraceae), and Kunkeliella subsuculenta (Santalaceae) from the Canary Islands (A. Valido, personal observation), and Daphne rodriguezii (Thymelaeaceae) from the Balearic Islands (Traveset and Riera, 2005), among others.

\section{Acknowledgements}

The work reported here was supported by grants from the Marie Curie European programme (grants MCFI-2000-1995 and MERG-CT-2004510260) and postdoctoral I3P (Ministerio de Ciencia y Tecnología, Spain) to A.V., and the Danish Science Research Council (J.M.O.). Many other researchers contributed with personal observations about frugivorous lizards, including L.J. Avila, A.M. Bauer, D. Bennett, D.G. Broadley, T.A. Carlo, C.L. Celedon-Neghme, E.J. Censky, J. Davenport, A. Fong, G. García, M. Gaulke, G. Gottsberger, D.H. Hansen, J.D. Lazell, L.V. Moreno, V. Parra-Tabla, R. Powell, L. Rodríguez-Schettino, G. Sorci, R. Swain, L.J. Vitt and A.H. Whitaker. Andrew Dennis, Hector Godínez-Alvarez, Pedro Jordano and Pierre-Michael Forget offered valuable comments on a previous draft. Finally, we would like to thank the organizers of the Symposium/Workshop, Andrew Dennis, Ronda Green, Eugene Schupp and David Westcott, for the invitation to contribute to this volume. 


\section{References}

Adamopoulou, C. and Legakis, A. (2002) Diet of a lacertid lizard (Podarcis milensis) in an insular dune ecosystem. Israel Journal of Zoology 48, 207-219.

Al-Johany, A. (1995) The ecology of Agama yemenensis Klausewitz (Lacertilia: Agamidae) in south-western Arabia. Journal of Arid Environments 29, 495-503.

Auffenberg, W. (1988) Gray's Monitor Lizard. University of Florida Press, Gainesville, Florida.

Auffenberg, W. and Auffenberg, T. (1988) Resource partitioning in a community of Philippine skinks (Sauria: Scincidae). Bulletin of the Florida State Museum, Biological Science 32, 151-219.

Ballinguer, R.E. and Ballinguer, R.A. (1979) Food resource utilization during periods of low and high food availability in Sceloporus jarrovi (Sauria: Iguanidae). Southwestern Naturalist 24, 347-363.

Barquín, E. and Wildpret, W. (1975) Diseminación de plantas canarias: datos iniciales. Vieraea 5, 38-60.

Baur, G. (1891) On the origin of the Galapagos Islands. American Naturalist 25, 217-229.

Bauer, A.M. and Sadlier, R.A. (2000) The Herpetofauna of New Caledonia. SSAR Publications, Ithaca, New York.

Barrett, S.C.H. (1998) The reproductive biology and genetics of island plants. In: Grant, P.R. (ed.) Evolution on Islands. Oxford University Press, Oxford, UK, pp. 18-34.

Beccari, O. (1877) Della disseminazione delle Palmae. Bolletino della Real Societá Toscana di Orticoltura Malesia 1, 1-16.

Belver, L.C. and Avila, L.J. (2002) Diet composition of Liolaemus bibronii (Iguania: Liogaemidae) in southern Rio Negro province, Argentine. Herpetological Journal 12, 39-42.

Benítez-Malvido, J., Tapia, E., Suazo, I., Villaseñor, E. and Alvarado, J. (2003) Germination and seed damage in tropical dry forest plants ingested by iguanas. Journal of Herpetology 37, 301-308.

Bennett, D. (2005) The ecology of Varanus olivaceus on Polillo Island and implications for other giant frugivorous lizards in the Philippines. Polillo Butaan Project: 2002-2005 [available at http://www.mampam.com/gfl].

Borzí, A. (1911) Ricerche sulla disseminazione delle piante per mezzo di Sauri. Memorie della Societe italiana delle scienze, detta dei XL Rome ser III 17, 97-115.

Brach, V. (1976) Habits and food of Anolis equestris in Florida. Copeia 1976, 187-189.

Búrquez, A., Flores-Villela, O. and Hernández, A. (1986) Herbivory in a small iguanid lizard, Sceloporus torquatus torquatus. Journal of Herpetology 20, 262-264.

Busack, S.D. and Jasick, F.M. (1982) Autoecological observations of Acanthodactylus erythrurus (Sauria: Lacertidae) in southern Spain. Amphibia-Reptilia 3, 237-255.

Calviño-Cancela, M. (2005) Fruit consumers and seed dispersers on the rare shrub Corema album, Empetraceae in coastal sand dunes. Revue d'Écologie La Terre et la Vie 60, 97-106.

Carlquist, S. (1974) Island Biology. Columbia University Press, New York.

Castilla, A.M. and Bawens, D. (1991) Observations on the natural history, present status, and conservation of the insular lizard Podarcis hispanica atrata on the Columbretes archipelago, Spain. Biological Conservation 58, 69-84.

Christian, K.A., Webb, J.L. and Schultz, T.J. (2003) Energetics of bluetongue lizards (Tiliqua scincoides). Oecologia 136, 515-523.

Churchill, S.K. (1994) Diet, prey selection and foraging behaviour of the orange horseshoebat. Rhinonycteris aurantius. Wildlife Research 21, 115-130.

Cobo, M. and Andreu, A.C. (1988) Seed consumption and dispersal by the spur-thighed tortoise Testudo graeca. Oikos 51, 267-273. 
Cogger, H.G., Cameron, E.E., Sadlier, R.A. and Eggler, P. (1993) The Action Plan for Australian Reptiles. Australian Nature Conservation Agency. Project 124 [available at http://www.deh.gov.au/biodiversity/threatened/action/reptiles/index.html].

Colli, G.R., Péres, A.K. and Zatz, M.G. (1997) Foraging mode and reproductive seasonality in tropical lizards. Journal of Herpetology 31, 490-499.

Cooper, W.E. and Vitt, L.J. (2002) Distribution, extent, and evolution of plant consumption by lizards. Journal of Zoology 257, 487-517.

Côrtes-Figueira, J.E., Vasconcellos-Neto, J., García, M.A. and Teixeira, A.L. (1994) Saurochory in Melocactus violaceus (Cactaceae). Biotropica 26, 295-301.

Darwin, C. (1845) The Voyage of the Beagle. Murray, London.

Dearing, M.D. and Schall, J.J. (1992) Testing models of optimal diet assembly by the generalist herbivorous lizard Cnemidophorus murinus. Ecology 73, 845-858.

de Armas, L.F. (1987) Notas sobre la alimentación de Leiocephalus carinatus cayensis (Sauria: Iguanidae). Poeyana 350, 1-7.

Ebenman, B. and Nilsson, S.G. (1982) Components of niche width in a territorial bird species: habitat utilization in males and females of the chaffinch (Fringilla coelebs) on islands and mainland. American Naturalist 119, 331-344.

Echternacht, A.C., Gerber, G.P. and Burton, F.J. (2000) Anolis conspersus (Grand Cayman blue-throated anole). Nectivory. Herpetological Review 31, 173.

Espinoza, R.E., Wiens, J.J. and Tracy, C.R. (2004) Recurrent evolution of herbivory in small, cold-climate lizards: breaking the ecophysiological rules of reptilian herbivory. Proceedings of the National Academy of Sciences 101, 16819-16824.

Estes, R. (1983) The fossil record and early distribution of lizards. In: Rhodin, A.G.J. and Miyata, K. (eds) Advances in Herpetology and Evolutionary Biology. Harvard University Press, Cambridge, Massachusetts, pp. 365-398.

Estrada, A. and Fleming, T.H. (1986) Frugivores and Seed Dispersal. Dr. W. Junk, Dordrecht, The Netherlands.

Fialho, R.F. (1990) Seed dispersal by a lizard and a treefrog: effect of dispersal site on seed survivorship. Biotropica 22, 423-424.

Fleming, T.H. (1991) Fruiting plant-frugivore mutualism: the evolutionary theater and the ecological play. In: Price, P.W., Lewinsohn, T.M., Fernandes, G.W. and Benson, W.W. (eds) Plant-Animal Interactions: Evolutionary Ecology in Tropical and Temperate Regions. Wiley, New York, pp. 119-144.

Fleming, T.H. and Estrada, A. (1993) Frugivory and Seed Dispersal: Ecological and Evolutionary Aspects. Kluwer, Dordrecht, The Netherlands.

Fölling, M., Knogge, C. and Böhmes, W. (2001) Geckos are milking honeydew-producing planthoppers in Madagascar. Journal of Natural History 35, 279-284.

Franzen, M. (1991) Beobachtungen zur phytophagen ernährung von Lacerta rudis und Lacerta clarkorum. Die Eidechse 2, 22-23.

Fructuoso, G. (1964) Las Islas Canarias de "Saudades de Terra". Instituto de Estudios Canarios, S/C Tenerife.

Godínez-Alvarez, H. (2004) Pollination and seed dispersal by lizards: a review. Revista Chilena de Historia Natural 77, 569-577.

Greeff, J.M. and Whiting, M.J. (1999) Dispersal of Namaqua fig (Ficus cordata cordata) seeds by the Augrabies flat lizard (Platysaurus broadleyi). Journal of Herpetology 33, 328-330.

Greene, H.W. (1982) Dietary and phenotypic diversity in lizards: why are some organisms specialized? In: Mossakowski, D. and Roth, G. (eds) Environmental Adaptation and Evolution. Gustav Fischer, Stuttgart, Germany, pp. 107-128.

Greer, A. (2005) Encyclopedia of Australian Reptiles. Australian Museum online [http://www. amonline.net.au/herpetology/research/encyclopedia.pdf, accessed 19 March 2005]. 
Griffiths, A.D. and Christian, K.A. (1996) Diet and habitat use of frillneck lizards in a seasonal tropical environment. Oecologia 106, 39-48.

Hartley, L.M., Glor, R.E., Sproston, A.L., Powell, R. and Parmer-Lee, J.S. (2000) Germination rates of seeds consumed by two species of rock iguanas (Cyclura spp.) in the Dominican Republic. Caribbean Journal of Science 36, 149-151.

Herrel, A., Vanhooydonck, B. and Joachim, R. (2004) Frugivory in polychrotid lizards: effects of body size. Oecologia 140, 160-168.

Herrera, C.M. (2002) Seed dispersal by vertebrates. In: Herrera, C.M. and Pellmyr, O. (eds) Plant-Animal Interactions: An Evolutionary Approach. Blackwell Publishing, Oxford, UK, pp. 185-208.

Hnatiuk, S.H. (1978) Plant dispersal by the Aldabran giant tortoise Geochelone gigantea (Schweigger). Oecologia 36, 345-350.

Hódar, J.A., Campos, F. and Rosales, B.A. (1996) Trophic ecology of the ocellated lizard Lacerta lepida in an arid zone of southern Spain: relationships with availability and daily activity of prey. Journal of Arid Environments 33, 95-107.

Howe, H.F. (1986) Seed dispersal by fruit-eating birds and mammals. In: Murray, D.R. (ed.) Seed Dispersal. Academic Press, New York, pp. 123-189.

Howe, H.F. and Smallwood, J. (1982) Ecology and seed dispersal. Annual Review of Ecology and Systematics 13, 201-228.

Howe, H.F. and Westley, L.C. (1988) Ecological Relationships of Plants and Animals. Oxford University Press, New York and Oxford.

Iverson, J.B. (1982) Adaptations to herbivory in iguanine lizards. In: Burghardt, G.M. and Rand, A.S. (eds) Iguanas of the World, Noyes Publishers, Park Ridge, New Jersey, pp. 60-76.

Iverson, J.B. (1985) Lizards as seed dispersers? Journal of Herpetology 19, 292-293.

Janzen, D.H. (1973) Sweep samples of tropical foliage insects: effects of seasons, vegetation types, elevation, time of day, and insularity. Ecology 54, 687-708.

Janzen, D.H. (1982) Natural history of guacimo fruits (Sterculiaceae: Guazuma ulmifolia) with respect to consumption by large mammals. American Journal of Botany 69, 1240-1250.

Janzen, D.H. (1983) Dispersal of seeds by vertebrates guts. In: Futuyma, D.J. and Slatkin, M. (eds) Coevolution. Sinauer, Sunderland, Massachusetts, pp. 232-262.

Jerozolimski, A. (2003) Dispersao de sementes por jabutis, Geochelone denticulata e G. carbonaria, na Amazònia oriental. VI Congresso de Ecologia do Brasil, Fortaleza, pp. 29-30.

Jordano, P. (1995) Angiosperm fleshy fruits and seed dispersers: a comparative analysis of adaptation and constraints in plant-animal interactions. American Naturalist 145, 163-191.

Jordano, P. (2000) Fruits and frugivory. In: Fenner, M. (ed.) Seeds: The Ecology of Regeneration in Plant Communities. CAB International, Wallingford, UK, pp. 125-165.

Jordano, P. and Schupp, E.W. (2000) Determinants of seed disperser effectiveness: the quantity component and patterns of seed rain for Prunus mahaleb. Ecological Monographs 70, 591-615.

Kiefer, M.C. and Sazima, I. (2002) Diet of juvenile tegu lizard Tupinambis merianae (Teiidae) in southeastern Brazil. Amphibia-Reptilia 23, 105-108.

King, G. (1996) Reptiles and Herbivory. Chapman and Hall, London.

Klein, E.H. (1977) Una contribución a los hábitos alimenticios del garrobo gris (Ctenosaura similis) en el sur de Honduras. Ceiba 21, 41-50.

Kuchling, G. (1970) Beobachtungen an Eumeces schneideri. Die Aquarien- und Terrarienzeitschrift 23, 216-217.

Labandeira, C.C. (2002) The history of associations between plants and animals. In: Herrera, C.M. and Pellmyr, O. (eds) Plant-Animal Interactions: An Evolutionary Approach. Blackwell Publishing, Oxford, UK, pp. 26-74. 
Larco, R. (2001) Los Mochicas II. Museo Arqueológico Rafael Larco Herrera y Fundación Telefónica, Lima.

Leguat (1981) The Voyage of Francois Leguat of Bresse to Rodriguez, Mauritius, Java, and the Cape of Good Hope. Vols I and II. Burt Franklin Publisher, New York.

Levey, D.J., Silva, W.R. and Galetti, M. (2002) Seed Dispersal and Frugivory: Ecology, Evolution and Conservation. CAB International, Wallingford, UK.

Liénard, F. (1842) Description de deux, espèces de Geckos de l'ile Rodrigues. Rapport annuel sur les travaux de la Société d'Histoire Naturelle de l'île Maurice 13, 55-57.

Liu, H., Platt, S.G. and Borg, C.K. (2004) Seed dispersal by the Florida box turtle (Terrapene carolina bauri) in pine rockland forests of the lower Florida Keys, USA. Oecologia 138, 539-546.

Lord, J.M. and Marshall, J. (2001) Correlations between growth form, habitat, and fruit colour in the New Zealand flora, with reference to frugivory by lizards. New Zealand Journal of Botany 39, 567-576.

Lord, J.M., Markey, A.S. and Marshall, J. (2002) Have frugivores influenced the evolution of fruits traits in New Zealand? In: Levey, D., Silva, W.R. and Galetti, M. (eds) Seed Dispersal and Frugivory: Ecology, Evolution and Conservation. CAB International, Wallingford, UK.

Mabberley, D.J. (1997) The Plant-Book: A Portable Dictionary of the Vascular Plants. Cambridge University Press, Cambridge, UK.

MacArthur, R.H., Diamond, J.M. and Karr, J.R. (1972) Density compensation in island faunas. Ecology 53, 330-342.

MacDonald, L.A. and Mushinsky, H.R. (1988) Foraging ecology of the gopher tortoise, Gopherus polyphemus, in a sandhill habitat. Herpetologica 44, 345-353.

Magnusson, W.E. and da Silva, E.V. (1993) Relative effects of size, season and species on the diets of some Amazonian savanna lizards. Journal of Herpetology 27, 380-385.

Mandujano, S., Gallina, S. and Bullock, S.H. (1994) Frugivory and dispersal of Spondias purpurea (Anacardiaceae) in a tropical deciduous forest in México. Revista de Biología Tropical 42, 107-114.

Mautz, W.J. and Lopez-Forment, W. (1978) Observations on the activity and diet of the cavernicolous lizard Lepidophyma smithii (Sauria: Xantusiidae). Herpetologica 34, 311-313.

Mellado, J., Amores, F., Parreño, F.F. and Hiraldo, F. (1975) The structure of a Mediterranean lizard community. Doñana, Acta Vertebrata 2, 145-160.

Mercolly, C. and Yanosky, A. (1994) The diet of adult Tupinambis teguixin (Sauria, Teiidae) in the eastern Chaco of Argentina. Herpetological Journal 4, 15-19.

Milton, S.J. (1992) Plants eaten and dispersed by adult leopard tortoises Geochelone pardalis (Reptilia: Chelonii) in the southern Karoo. South African Journal of Zoology 27, 45-49.

Moll, D. and Jansen, K.P. (1995) Evidence for a role in seed dispersal by two tropical herbivorous turtles. Biotropica 27, 121-127.

Morales-Mávil, J.E., Sánchez-Marín, M.L. and Domínguez-Domínguez, L.E. (2005) Comparación de la germinación de semillas de Spondias mombin ingeridas por la Iguana verde (Iguana iguana), el Tucán (Ramphastos sulfuratus) y el Mono araña (Ateles geoffroyii). In: Reynoso, V.H. and Madinah, W. (eds) VII Reunión Nacional sobre Iguanas en México. IBUNAM, Michoacán, Mexico, pp. 93-99.

Murphy, T.J. and Myers, A.A. (1996) The behavioural ecology of Phelsuma astriata semicarinata on Aridae Island Nature Reserve, Seychelles. Journal of Herpetology 30, 117-123.

Nogales, M., Nieves, C., Illera, J.C., Padilla, D.P. and Traveset, A. (2005) Effect of native and alien vertebrate frugivores on seed viability and germination patterns of Rubia fruticosa (Rubicaceae) in the eastern Canary Islands. Funtional Ecology 19, 429-436. 
O'Grady, S.P., Morando, M., Avila, L. and Dearing, M.D. (2005) Correlating diet and digestive tract specialization: examples from the lizard family Liolaemidae. Zoology 108, 201-210.

Olesen, J.M. and Jordano, P. (2002) Geographic patterns in plant-pollinator mutualistic networks. Ecology 83, 2416-2424.

Olesen, J.M. and Valido, A. (2003) Lizards as pollinators and seed dispersers: an island phenomenon. Trends in Ecology and Evolution 18, 177-181.

Olesen, J.M. and Valido, A. (2004) Lizards and birds as generalized pollinators and seed dispersers of island plants. In: Fernández-Palacios, J.M. and Morici, C. (eds) Island Ecology. AEET/ Cabildo Insular de La Palma, pp. 229-249.

Ortiz, J.C. (1975) Una nueva especie de lagartija chilena, Liolaemus donosoi sp. nov. (Squamata-Iguanidae). Anales del Museo de Historia Natural del Valparaíso 8, 62-65.

Ortiz, J.C. and Riveros, J.M. (1976) Hábitos alimenticios de Liolaemus nigromaculatus kuhlmani, Müller y Hellmich. Anales del Museo de Historia Natural Valparaíso 9, 131-140.

Patterson, G.B. (1992) The ecology of a New Zealand grassland lizard guild. Journal of the Royal Society of New Zealand 22, 91-106.

Patterson, K. (1928) Amphibians and Land Reptiles of Porto Rico, with a list of those reported from the Virgin Islands: Scientific Survey of Porto Rico and the Virgin Islands. Volume X, Part I. New York Academy of Sciences, New York.

Pearson, O. (1954) Habits of the lizard Liolaemus multiformis multiformis at high altitudes in southern Peru. Copeia 2, 111-116.

Péres, A.K. (2003) Sistemática e Conservação de lagartos do gênero Tupinambis (Squamata, Teiidae). PhD thesis, University of Brasília, Brazil.

Pérez-Mellado, V. and Corti, C. (1993) Dietary adaptations and herbivory in lacertid lizards on the genus Podarcis from western Mediterranean islands (Reptilia: Sauria). Bonner Zoologische Beiträge 44, 193-220.

Pérez-Mellado, V. and Traveset, A. (1999) Relationships between plants and Mediterranean lizards. Natura Croatica 8, 275-285.

Pérez-Mellado, V., Riera, N., Perera, A. and Martín-García, S. (2005) The lizard, Podarcis lilfordi (Squamata: Lacertidae) as a seed disperser of the Mediterranean plant, Phillyrea media (Oleaceae). Amphibia-Reptilia 26, 105-108.

Pietruszka, R.D., Hanrahan, S.A., Mitchell, D. and Seely, M.K. (1986) Lizard herbivory in a sand dune environment: the diet of Angolosaurus skoogi. Oecologia 70, 587-591.

Racine, C.H. and Downhower, J.F. (1974) Vegetative and reproductive strategies of Opuntia (Cactaceae) in the Galapagos Islands. Biotropica 6, 175-186.

Rand, A.S. (1978) Reptilian arboreal folivores. In: Montgomery, G.G. (ed.) The Ecology of Arboreal Folivores. Smithsonian Institution Press, Washington, DC.

Rick, C.M. and Bowman, R.I. (1961) Galápagos tomatoes and tortoises. Evolution 15, 407-417.

Ridley, H.N. (1930) The Dispersal of Plants Throughout the World. Lovell Reeve \& Co., Ashford, UK.

Rodda, G.H. and Dean-Bradley, K. (2002) Excess density compensation of island herpetofauna assemblages. Journal of Biogeography 29, 623-632.

Rodda, G.H., Perry, G., Rondeau, R.J. and Lazell, J. (2001) The densest terrestrial vertebrate. Journal of Tropical Ecology 17, 331-338.

Rodríguez-Pérez, J., Riera, N. and Traveset, A. (2005) Effect of seed passage through birds and lizards on emergence rate of Mediterranean species: differences between natural and controlled conditions. Functional Ecology 19, 699-706.

Rogner, M. (1997) Lizards. Vols I and II. Krieger Publishing Company, Malabar, Florida.

Rust, R.W. and Roth, R.R. (1981) Seed production and seedling establishment in the mayapple, Podophyllum peltatum. American Midland Naturalist 105, 51-60.

Salvador, A. (1986) Podarcis pityusensis (Boscá, 1883) - Pityusen-Eidechse. In: Böhme, W. (ed.) Handbuch der Reptilien und Amphibien Europas: Echsen III (Podarcis). Aula-Verlag Wiesbaden, Wiesbaden, Germany, pp. 231-253. 
Schleich, H.H., Kästle, W. and Kabisch, K. (1996) Amphibians and Reptiles of North Africa. Koeltz Scientific, Koenigstein, Germany.

Schoener, T.W., Slade, J.B. and Stinson, C.H. (1982) Diet and sexual dimorphism in the very catholic lizard genus Leiocephalus of the Bahamas. Oecologia 53, 160-169.

Schupp, E.W. (1993) Quantity, quality and the effectiveness of seed dispersal by animals. Vegetatio 107/108, 15-29.

Schwartz, A. and Henderson, R.W. (1991) Amphibians and Reptiles of the West Indies: Descriptions, Distributions, and Natural History. University of Florida Press, Gainesville, Florida.

Spencer, N.J., Thomas, B.W., Mason, R.F. and Dugdale, J.S. (1998) Diet and life history variation in the sympatric lizards Oligosoma nigriplantare polychronma and Oligosoma lineoocellatum. New Zealand Journal of Zoology 25, 457-463.

Steindacher, F. (1891) Üeber die Reptilien und batrachier der westl. und östl. Gruppe der Canarischen Inseln. Annalen des k. k. naturhistorischen Hofmuseums 6, 287-306.

Stiles, E.W. (1989) Fruits, seeds, and dispersal agents. In: Abrahamson, W.G. (ed.) Plant-Animal Interactions. McGraw-Hill, New York, pp. 87-122.

Struck, U., Altenbach, A.V., Gaulke, M. and Glaw, F. (2002) Tracing the diet of the monitor lizard Varanus mabitang by stable isotope analyses $\left(\delta^{15} \mathrm{~N}, \delta^{13} \mathrm{C}\right)$. Naturwissenschaften 89, 470-473.

Symon, D.E. (1979) Fruit diversity and dispersal in Solanum in Australia. Journal of the Adelaide Botanical Gardens 16, 321-331.

Tiffney, B.H. (2004) Vertebrate dispersal of seed plants through time. Annual Review of Ecology and Systematic 35, 1-28.

Traveset, A. (1990) Ctenosaura similis Gray (Iguanidae) as a seed disperser in a Central American deciduous forest. American Midland Naturalist 123, 402-404.

Traveset, A. (1998) Effect of seed passage through vertebrate frugivores' guts on germination: a review. Perspectives in Plant Ecology, Evolution and Systematics 1/2, 151-190.

Traveset, A. and Riera, N. (2005) Disruption of a plant-lizard seed dispersal system and its ecological effects on a threatened endemic plant in the Balearic Islands. Conservation Biology 19, 421-431.

Traveset, A. and Sáez, E. (1997) Pollination of Euphorbia dendroides by lizards and insects: spatio-temporal variation in patterns of flower visitation. Oecologia 111, 241-248.

Traveset, A. and Verdú, M. (2002) A meta-analysis of the effect of gut treatment on seed germination. In: Levey, D., Silva, W.R. and Galetti, M. (eds) Seed Dispersal and Frugivory: Ecology, Evolution and Conservation. CAB International, Wallingford, UK, pp. 339-350.

Troyer, K. (1984) Diet selection and digestion in Iguana iguana: the importance of age and nutrient requirements. Oecologia 61, 201-207.

Uetz, P. (2005) The EMBL Reptile Database (CD, March 2005).

Ussher, G.T. (1999) Tuatara (Sphenodon punctatus) feeding ecology in the presence of kiore (Rattus exulans). New Zealand Journal of Zoology 26, 117-125.

Valido, A. (1999) Ecología de la dispersión de semillas por los lagartos endémicos Canarios (g. Gallotia, Lacertidae). PhD thesis, University of La Laguna, Tenerife, Canary Islands.

Valido, A. and Nogales, M. (1994) Frugivory and seed dispersal by the lizard Gallotia galloti (Lacertidae) in a xeric habitat of the Canary Islands. Oikos 70, 403-411.

Valido, A. and Nogales, M. (2003) Digestive ecology of two omnivorous Canarian lizard species (Gallotia, Lacertidae). Amphibia-Reptilia 24, 331-344.

Valido, A., Nogales, M. and Medina, F.M. (2003) Fleshy fruits in the diet of Canarian lizard Gallotia galloti (Lacertidae) in a xeric habitat of the island of Tenerife. Journal of Herpetology 37, 741-747.

van Damme, R. (1999) Evolution of herbivory in lacertid lizards: effects of insularity and body size. Journal of Herpetology 33, 663-647. 
van der Pijl, L. (1982) Principles of Dispersal of Higher Plants. Springer, Berlin, Heidelberg, and New York.

Varela, R.O. and Bucher, E.H. (2002) The lizard Teius teyou (Squamata: Teiidae) as a legitimate seed disperser in the dry Chaco Forest of Argentina. Studies on Neotropical Fauna and Environment 37, 115-117.

Vega, L.E., Chani, J.M. and Trivi, M. (1988) Observations on the feeding habits of Ameiva ameiva. Herpetological Review 19, 53-54.

Vitt, L.J. (2004) Shifting paradigms: herbivory and body size in lizards. Proceedings of the National Academy of Sciences 101, 16713-16714.

Vitt, L.J. and Carvalho, C.M. (1995) Niche partitioning in a tropical wet season: lizards in the Lavrado area of Northern Brazil. Copeia 1995, 305-329.

Vitt, L.J. and Pianka, E.R. (2005) Deep history impacts present-day ecology and biodiversity. Proceedings of the National Academy of Sciences 102, 7877-7881.

Vitt, L.J., Zani, P.A., Caldwell, J.P., Araújo, M.C. and Magnusson, W.E. (1997) Ecology of whiptail lizards (Cnemidophorus) in the Amazon region of Brazil. Copeia 1997, 745-757.

Walls, G.Y. (1981) Feeding ecology of the tuatara (Sphenodon punctatus) on Stephens Island, Cook Strait. New Zealand Journal of Ecology 4, 89-97.

Wells, H. and King, J.L. (1980) A general 'exact test' for $\mathrm{N} \times \mathrm{M}$ contingency tables. Bulletin of the Southern California Academy of Science 79, 65-77.

Weiser, P.J., Weiser, J.N. and Robres, L. (1975) Notes on cactus flower predation by lizards in the Atacama desert. Aloe 13, 117-118.

Whitaker, A.H. (1968) The lizards of the Poor Knights Islands, New Zealand. New Zealand Journal of Science 11, 623-651.

Whitaker, A.H. (1987) The roles of lizards in New Zealand plant reproductive strategies. New Zealand Journal of Botany 25, 315-328.

Willson, M.F., Sabag, C., Figueroa, J., Armesto, J.J., and Caviedes, M. (1996) Seed dispersal by lizards in Chilean rainforest. Revista Chilena de Historia Natural 69, 339-342.

Wotton, D.M. (2002) Effectiveness of the common gecko (Hoplodactylus maculatus) as a seed disperser on Mana Island, New Zealand. New Zealand Journal of Botany 40, 639-647.

Yasuda, M., Miura, S., Ishii, N., Okuda, T. and Hussein, N.A. (2005) Fallen fruits and terrestrial vertebrate frugivores: a case study in a lowland tropical rainforest in peninsular Malaysia. In: Forget, P.-M., Lambert, J.E, Hulme, P.E. and Vander Wall, S.B. (eds) Seed Fate: Predation, Dispersal and Seedling Establishment. CAB International, Wallingford, UK, pp. 151-174. 